\title{
Teaching Basic Skill of Economic Education University students
}

\author{
Ripho Delzy Perkasa, Dian Shaumia \\ Faculty of Education Science \\ Universitas Mahaputra Muhammad Yammin \\ Solok, Indonesia \\ rdp_mpd@yahoo.co.id
}

\begin{abstract}
This research aims to determine and analyze: 1) teaching basic skill of Economic Education University students' UMMY Solok education year of 2013, 2) Improvement of teaching basic skill of Economic Education University students' UMMY Solok after it is given material knowledge of teaching basic skill in Micro Teaching course, 3) weaknesses or shortages of university students in mastering the teaching basic skill of Economic Education University students' UMMY Solok. Type of research is qualitative research. This research was conducted in UMMY Solok Campus and Mitra School, university students' places taking Educational Field Practice in Odd semester academic year of 2016/2017. Data collection devices in this research are the researchers and teams given interview guidance, observation guidance and documentation to guarantee data validity giving more references on credibility standard because the standard was well-adjusted and easier to be analyzed so that the data and the research would be more accurate. The guarantee of data validity through this standard was conducted through more careful observation and data triangulation. Results of the research indicate that the Education Field Practice University students, Economic Education Faculty of Education Science UMMY Solok education year 2013 have been in good category, ranging from skills to start course until to learning closing activity. Also, there has been improvement felt by the university students after they are given knowledge of teaching basic skill in micro teaching course, although there are still any weaknesses or shortages in mastering learning basic skill, particularly in basic skill of explaining. University students should be more prepared in conducting the teaching and learning process, in particular in mastering the materials, so that the university students can minimize any weakness in mastering the basic skill of explaining. Also, the university students should be read more other references other than package books used at the time of teaching process so that the university students' material mastering at the teaching process will be better.
\end{abstract}

Keywords- Teaching Basic Skill, University students, Economic Education

\section{INTRODUCTION}

\section{A. Background Problem}

Learning is a system which there are various intercorrelated and cooperated components to achieve the learning objectives [1]. Therefore, in order to achieve the learning objectives in appropriate manner, all of the involved components in the learning process should be organized as proper as possible in the proper planning format [2], [3], so that at the time of learning process, minimally there are fewer errors caused by misappropriated component replacement or selection.

Teacher teaching basic skill is a manifestation of teacher acquisition on his or her competence. The teaching basic skill is the most absolute and must be possessed by every prospective teacher ranging from basic skill of opening course until to the basic skill of closing course [4], [5]. Skill of a prospective teacher in mastering teaching basic skill will be a benchmark for a teacher's success in managing teaching and learning activity in the class and contrary, a prospective teacher having no ability to master the basic skill in managing teaching and learning activity in the class, so it is very important for a prospective teacher to obtain adequate provisions so that he or she can master a number of basic skill that should be possessed by a prospective teacher so that the desired learning objectives in the learning process can be achieved appropriately [6].

Teaching is not a simple process but it is a very complex process. Teaching is a process with abundance aspects ranging from providing information, proposing questions, explaining, listening, encouraging and a number of other activities [7]. Teaching is a work or effort to encourage university students to conduct the learning activity. A teacher's task and responsibility is managing learning process to be more effective, dynamic and positive; these are signed by awareness and active involvement between two courses, namely teacher and student.

This research has background from result of odd semester findings in education year of 2015/2016 in teaching practices in economic education media course. From the findings, there was $\geq 80 \%$ economic education university student's year 
education of 2013 that could not understand the teaching basic skill that should be possessed by a teacher or can be said that the university students were yet able to conduct the teaching practice in the class [8]. The teaching basic skill minimally that should be possessed by the university students is basic skill of explaining, skill of making variations, skill of strengthening and basic skill of class management [2].

The facts in the field at teaching practices are that there were many university students with no ability to explain the materials appropriately. This was signed by many university students feeling nervous when explaining teaching materials, one of the concepts in explaining teaching materials. Another condition at teaching practice shows that there were many university students having no ability to conduct variations in teaching, either voice, expression variation or variation in using teaching learning method or strategy. Meanwhile, in skill of providing strengthening, there were many university students having no care to students when they conduct positive or negative activity as well as they were also seen to be busy in the teaching materials.

A series of facts in the field are still understood because basically, teaching basic skill knowledge will be fully obtained by the university students in micro teaching course at this odd semester taken by the students. When the university students have learned the concepts or basic knowledge related to the teaching basic skills, they should be obtain better teaching basic skill than previously. This encourages the writer to conduct a research related to the teaching basic skill of economic education university students' after they were given Micro Teaching course presented in the research entitled "Teaching Basic Skills of Economic Education Students UMMY Solok education year of 2013"

\section{B. Research Focus}

The focus in this research can be described in the research questions as follow:

- How is teaching basic skill of economic education university students' UMMY Solok.

- Is there any improvement of teaching basic skill of economic education university students' of UMMY Solok after they are provided the teaching basic skill material knowledge in micro teaching course?

- Are there are any weaknesses or shortages in mastering teaching basic skill by economic education university students of UMMY Solok..

\section{RESEARCH METHOD}

\section{A. Research Stages}

The research stages conducted in this research are [9], [10]:

\section{1) Preliminary Stage}

This stage is started by studying any problems by identifying any problems that can be described in the problem formulation related to the literature study concerning similar studies.

\section{2) Data Collection Stage}

This stage is the research core stage. The researchers conducted the research through observation, interview and observation techniques. The researchers are not only served as research applicators, but they also serve as the research main instruments. These research data are obtained through two stages, namely: 1) preliminary observation activity namely general and broad observation, 2) description results from focused observation.

\section{3) Data Processing Stage}

This data collection can be conducted through observation, interview, and documentation techniques.

\section{4) Analysis and Discussion Stage}

Collected data are analyzed; the results will be commented by the researchers from the research implementation to draw conclusion and compare with previous researchers, seeing the research implication and providing recommendations or suggestions.

\section{FINDINGS AND DISCUSSION}

\section{A. Findings}

1) Teaching Basic Skills of Economic Education University Students Faculty of Education Science of UMMY Solok

Teaching basic skills are main basic factors that should be possessed by a university student as a prospective teacher in order to improve the learning quality. This is based on a reality that teaching is not that easy, a teacher's task is not only about providing knowledge, but also how to be able to create a meaningful learning. This seems to be impossible if a prospective teacher does not have any adequate teaching basic skills, ranging from basic skill of opening lessons until basic skill of closing a course.

In this research, the university student's teaching basic skills are analyzed through Educational Field Practices obtained from the guardians and interview with the students' guardians. The researchers obtain data assessment results of teaching basic skills by Economic Education university students of Faculty of Education Science of UMMY Solok as follow: 
TABLE I. TEACHING BASIC SKILl DATA By ECONOMIC EDUCATION STUDENTS' FACULTY OF EDUCATION SCIENCE UMMY SOLOK EDUCATION YEAR OF 2013

\begin{tabular}{|c|c|c|c|}
\hline No & $\begin{array}{c}\text { Teaching Basic } \\
\text { Keterampilan Dasar } \\
\text { Mengajar }\end{array}$ & Scores & Total (\%) \\
\hline 1 & Designing RPP & $\begin{array}{l}73.50-77.49 \\
77.50-80.49 \\
81.50-85.49 \\
85.50-89.49 \\
>89.50\end{array}$ & $\begin{array}{l}7.69 \\
2.56 \\
35.90 \\
25.64 \\
28.21\end{array}$ \\
\hline 2 & Opening lessons & $\begin{array}{l}73.90-77.89 \\
77.90-81.89 \\
81.90-85.89 \\
85.90-89.89 \\
>89.90\end{array}$ & $\begin{array}{l}5.13 \\
17.95 \\
25.64 \\
23.08 \\
7.69\end{array}$ \\
\hline 3 & Material Acquisition & $\begin{array}{l}70.60-75.59 \\
75.60-80.59 \\
80.60-85.59 \\
85.60-90.59 \\
>90.60\end{array}$ & $\begin{array}{l}7.69 \\
15.39 \\
48.72 \\
12.82 \\
15.39\end{array}$ \\
\hline 4 & Class Management & $\begin{array}{l}73.30-77.29 \\
77.30-81.29 \\
81.30-85.29 \\
85.30-89.29 \\
>89.30\end{array}$ & $\begin{array}{l}7.69 \\
7.69 \\
46.15 \\
28.21 \\
10.26 \\
\end{array}$ \\
\hline 5 & Media Use & $\begin{array}{l}73.50-74.49 \\
77.50-81.49 \\
81.50-85.49 \\
85.50-89.49 \\
>89.50\end{array}$ & $\begin{array}{l}7.69 \\
15.39 \\
41.03 \\
25.64 \\
10.26\end{array}$ \\
\hline \multirow[t]{4}{*}{6} & Varied Questions & $\begin{array}{l}73.70-77.69 \\
77.70-81.69 \\
81.70-85.69 \\
85.70-89.69 \\
>89.70\end{array}$ & $\begin{array}{l}7.69 \\
12.82 \\
46.15 \\
17.95 \\
7.69\end{array}$ \\
\hline & Varied Method & $\begin{array}{l}73.00-76.99 \\
77.00-80.99 \\
81.00-84.99 \\
85.00-88.89 \\
>89\end{array}$ & $\begin{array}{l}7.69 \\
15.39 \\
43.59 \\
20.51 \\
7.69\end{array}$ \\
\hline & Voice Intonation & $\begin{array}{l}73.20-77.19 \\
77.20-81.19 \\
81.20-85.19 \\
85.20-89.19 \\
>89.20\end{array}$ & $\begin{array}{l}5.13 \\
10.26 \\
38.46 \\
23.08 \\
7.69 \\
\end{array}$ \\
\hline & Strengthening & $\begin{array}{l}74.00-77.99 \\
78.00-81.99 \\
82.00-85.99 \\
86.00-89.99 \\
>90.00\end{array}$ & $\begin{array}{l}10.26 \\
17.85 \\
43.59 \\
15.39 \\
5.13 \\
\end{array}$ \\
\hline 7 & Performance & $\begin{array}{l}73.60-77.59 \\
77.60-81.59 \\
81.60-85.59 \\
85.60-89.59 \\
>89.60\end{array}$ & $\begin{array}{l}2.56 \\
7.69 \\
28.21 \\
43.59 \\
20.51 \\
\end{array}$ \\
\hline 8 & Closing lessons & $\begin{array}{l}74.00-77.99 \\
78.00-81.99 \\
82.00-85.99 \\
86.00-89.99 \\
>90.00\end{array}$ & $\begin{array}{l}2.56 \\
10.26 \\
53.85 \\
17.95 \\
15.39 \\
\end{array}$ \\
\hline
\end{tabular}

2) Improvement of Teaching Basic Skills After Provision of Material Knowledge of Teaching Basic Skills in Micro Teaching Course

The micro teaching is used in order to develop teaching basic skill of a prospective teacher. Basically, the micro teaching is divided into two stages; the first stage is conducted in the $1^{\text {st }}$ until $17^{\text {th }}$ week; the students are given various teaching basic skills ranging from teaching basic skill of opening lessons until closing a course. Meanwhile, in the $9^{\text {th }}$ until $16^{\text {th }}$ week, the students conduct the teaching practices through assessment conducted by application of teaching basic skills that has been understood by the students. It is expected that after they are given the teaching basic skills through the micro teaching, the students are realy able to understand and apply the teaching basic skills appropriately at the PLK.

Based on interviews with course teachers in schools on March, 7 and 9, 2017 related to basic skills of opening lessons, students have been able to apply these basic skills appropriately; in this stage activity, students are always doing apperception, checking absentee, and looking at students' preparedness to learn before the teaching and learning process.

"So, I think that based on my observation, if the skill of opening lessons can be encouraged through TPQ activities; TPQ activities can be in the forms of local observation; students' preparedness in starting lesson; afterward, preparation for students to pray before the learning process; then, checking absent; delivery of Basic Competence (KD) at this meeting; then, followed the delivery of indicators that will be submitted in the learning process along with the intended objectives. So, the learning activities are done (Biksun, Smantri)"

Further, the teachers from Smansa also said that PLK university students of Economic Education of FKIP UMMY Solok in the preliminary activity has been able to conduct the activity very well and has been based on the RPP (Learning Application Design) created by the students at each meeting.

"Probably because I can get the best student from the Economics Education Faculty of Education Science of UMMY UMMY Solok, so my OT students, starting from the guided activities until the self-supporting activities have carried out preliminary activities or opening activities very well. My schedule is not much complicated with my OT students and is very much different from my OT student last year"

Based on the students' opinion related to the improvement of basic teaching skills in micro teaching course, the students revealed that that has been an improvement of skills to open and close lesson before and after they were given materials in micro teaching course.

"As I progressed to the teaching process, there is an increase on my skills in opening lessons; I began to develop ways to attract my students to join the lessons when I open the lessons (SY interview on 4 and 6 April2017)".

Further, FY, YM, YD and YF said that after understanding the basic skill of opening lesson as an important part in the teaching and learning process through micro teaching, they obtained more understanding about preliminary activities as the 
key role in good teaching and learning management, as they said as follow:

"Opening a lesson is the first activity a teacher should undertake when undertaking a learning activity. If there is no opening activity or it does not go according to the desired one by the students then, the learning will not run properly. Therefore, at the time of basic skills training to teach skill of opening lesson, it is greatly emphasized so that at the time of field education practice, the students can open the lesson well".

So, it can be concluded that based on the findings, there is an improvement on the students' skill of opening a lesson after they are given material knowledge of teaching basic skill in micro teaching course [11].

There is an improvement on the basic skills of material mastery or basic of explaining by the students than when the micro teaching learning; based on the students, they think that their students have started to understand what they teach to them; however based on advice by a guardian teacher, they still have to learn a lot from various references and voice intonations also should be considered as an excerpt of interviews conducted with SY.

"In explaining the materials, I have been good and able to make students understand what I teach; these can be seen from the exercises results and their independent activity results; my weakness is the voice intonation in explaining, it tends to be flat, thus making the students difficult to distinguish the concept with explanation. Advice from the guardian is that teachers should give more attention to the voice intonation in teaching because it will affect on the students' understanding of the material (Interview on 4 and 6 April 2017 ').

In further, YD, ZA and WYM said that after understanding that the teacher skill in explaining materials, it is very influential on delivering message to the message's recipients through micro teaching learning; they began to develop their knowledge through various sources so that they can obtain more knowledge and by the provision, they can deliver more messages to students (interview 11 and 13 April 2017).

In the basic skills of classroom management, after being equipped with this knowledge on micro teaching, the students increasingly understand that the success of a teaching and learning process also depends on teacher's ability in class management. Any teacher's having good skill in explaining but if he or she is not able to manage the class well, then it will be easy to find out any fussed confused students in the class; this will lead to not conducive class (FY interview on 4 and 6 April 2017).

Furthermore, the guidance teacher of Smansa, Smatri and Biksun also said that in managing class, the students of Economics Education Faculty of Education UMMY Solok have good skills; this can be seen from a few students making negative activities in the class so that the class has started to be conducive. In addition, through supervision and permission from guidance teachers, the students have been able to provide any strengthening or punishments that can be given to students who violate the predetermined rules.
"In managing class, we are required to arrange students' seats in accordance with their characters; it is often forgotten. Students do not have their own rules of learning; they just follow their guidance rules. The class management skill can be well applied in the middle of OT. For the positive one, it was given strengthening for example; it is good and can be improved more; for the negative one, it was given strengthening such as students' assertiveness in giving warning for any students who come in and out in of the classroom. Related to the weakness in providing strengthening, sometimes the students forget to give reward for students who answer questions (interview 7 and 9 March 2017)".

For teaching basic skill of media use, average students have no appropriate understanding on the teaching media role in the class, so that at the OT, the students rarely use varied learning media in the teaching and learning process. Most students only depend on the package books. So that when the researchers conducted field interview, it was a complaint by the guidance teacher. This is the excerpt of interview conducted by the researchers and SY and YM on 4 and 6 April 2017.

"In my opinion, in the use of media I still use lack media, because in teaching I rarely use media other than existing books at school. Suggestions for the future: Increase variations in media usage at the teaching process because it can increase students' interest to learn".

Furthermore, YM explained that he tended to rely on package book at the teaching and learning process because the Power Point that has been prepared before class was not used because of the limited infocus facility as well as to use it, he should stay in line with other teachers. This led to his reluctance to use the media and he more relied to the package book and lecturing method at the teaching and learning process.

"One of the instructional media characteristics is that media contain and carry message or information to students. Through media, students can process messages and provide more focus respond in learning process. But, we create media with purpose to meet the learning needs and student abilities. Teachers should use the media at the learning process, namely at lecturing method. By using media on the lecturing method, it will be more effective, because students will be interested in the media, only if the media are really in accordance with the material that teachers teach. Each media must have advantages and disadvantages. For example, in an image media, it is only suitable for a class with a small number of students; if the number of students in that class is too big, it will be not suitable to use the image media; because it will be less clear for any students sitting on the back. This is what I experienced at the OT, because of many students, the media that I created were not effective. They reasoned that the media were less clearly at backward. I was trying to create a media, because of lecturing method application. My reason in making image media is that it is not too difficult, with the image, I try to make students interested and active in learning, although there are some active students. Because the image media I created was less effective, then I replaced it with Power Point using infocus. Here, I also faced any constraints, because the school where I did the OT, was not using infocus, so I borrowed the 
infocus from the Vice school principal room. By making power point, overall students were able to see the pictures and also interested in the lessons being taught, the students were more actively asking, but the problem was the limited available infocus, so I rarely used the media. Because other teachers first borrowed the infocus and eventually the infocus should be used interchangeably. So, I was only using the lecturing method, this would make students quickly bored and took turns asking for permission to leave the classroom".

For the basic skill of questioning, OT university students' of Economic Education FKIP UMMY Solok have been well based on the guidance teachers in Smantri, Smansa and Biksun. They think that this activity was always applied though there were not many students asking questions. The students have been able to ask basic questions such as testing students' basic knowledge until any questions measuring students' analysis skill (interview on 7 and 9 March 2017).

"The questioning skill is to ask questions. But sometimes maybe as teachers, we do not ask not to all students, we just do only to smart".

"Because there are many Economic course matters related to analysis, so that more students are asking analysis questions. Seeing at students' tendency, the asking skill can be divided into 80 analysis and 20 knowledge, the weakness is in the skill of questioning in the use of language."

Furthermore, FY also expressed that in the teaching basic skill of questioning, they have been able to conduct and apply the skill in the class as well as they have understood that this skill is important to be owned by a prospective teacher because it relates to the students' understanding. The following is the interview excerpt with FY:

"The basic skill of questioning is the skill that should be possessed by a prospective teacher; by having the basic skill of questioning by the student (a prospective teacher) at the time of field education practice, the student no longer feel nervous to ask the participants. Therefore, at the time of briefing, the students should be able to provide questions to students about the material being taught, with the basic skills of questioning, the students concerned will know their students' understanding of the materials that have been studied".

In the basic skill of varied methods, OT students of Economic Education FKIP UMMY Solok have less ability, with other words there is no adequate improvement on the basic skill of varied method before they are given material knowledge of teaching basic skill in micro teaching course. This is based on the students' statements that at the time of material strengthening of basic skill of varied method, they are more focused on basic skill of explaining, class management and media use. This influences on understanding and application of learning method use at school; the practice is more oriented to the use of lecturing method, as expressed by YF, FY and ZA as follow:

"The skill of using method at the time of field training is less because at the time of teaching, the more dominant skills are explaining, media usage and class management, so there is less teaching method. At the time of field education practice, it is rarely used the teaching methods, so when the OT, it is more prioritized to explain the material to students than using the methods. It is only using lecturing methods as the teaching materials to students (interview 4 and 6 April 2017)".

Furthermore, SJ expressed that the use of varied learning method tends to lead to low students' learning interest and they should explain the materials in repeated manner; thus this takes much time during teaching and learning process.

"My ability to make variations in the learning method, in my opinion is still lacking, because I only apply methods of questioning and answering, lecturing and discussions; this is likely to make students bored and give less attention to the learning process. So, I have to repeat the materials while teaching. Suggestion from the guardian: trying to use a variety of methods in teaching so that the materials presented can attract students' interest to learn (interview 4 and 6 April 2017)",

In the teaching basic skill of providing strengthening, the OT students of Economic Education FKIP UMMY Solok have obtained meaningful improvement. This is based on the statement of Bisun guardian stating that the students have been able to provide strengthening to their students in the class during teaching and learning process, either positive or negative strengthening. The following is the interview excerpt between the researchers and the Bisun economic teacher:

"The positive strengthening is re in the form of saying good, you can improve it; for the negative one, it can be in the form of strict warning to students who come in and out in of the classroom. The weakness in providing strengthening, sometimes students forget to give reward to students who answer questions (interview March 2017)".

Furthermore economic teachers in Smansa and Smantri also expressed that there is strict warning given by the OT students to any students violating rules or discipline determined by school; the students have been able to provide appropriate sanctions and always coordinate with the guardian teachers.

So, from the research findings, it can be concluded that there has been an improvement on teaching basic skills by the economic education students of FKIP UMMY Solok after they are given material knowledge of teaching basic skills in Micro Teaching course.

3) Weaknesses in Mastering Teaching Basic Skills by Economic Education Students FKIP UMMY Solok

For basic skill of material mastering or explaining, students are still assessed to have the low skill. This is based on their incapability to build concepts from the materials that they teach. Ideally, the concepts to be built by a teacher are based on the closed fact findings from the students; the students are not applied this appropriately in which the students directly explain the materials at the time of building materials without relating any concepts from the students. This is expressed by economic teachers from Smantri, Smansa and Smantri:

"In explaining, the OT students often go directly to the concepts; actually they should not be too direct, there should be examples or facts built by students to find their own concepts. But, I understand this can be caused by their less experiences; 
we as the experienced ones, sometime also do the same thing (Smansa and Smantri interview on 7 and 9 March 2017)".

Furthermore, Vice Curriculum of Smantri also expressed that the explaining skill of economic education students is still standard meaning that the students' explaining skill is still low, as expressed from the interview as follow:

"In general, guardian teachers report the material to the vice curriculum, actually they are expected to provide unusual materials namely more than the standard; it means that the material mastery is expected to be more. Actually, we can set the strategy, for example when we are less mastering the materials, we can ask the children to read the book first, at that time we as the teachers also read, this way can make us obtain more understanding on the materials. Actually, there is no difficulty in teaching, just it is a matter of setting strategy". Besides, the students also state that their teaching basic skills are still low, in particular related to the basic skill of explaining.

Field Experience Education is one of the intra-curricular activities undertaken by students including teaching exercises as well as teaching tasks beyond guided and integrated teaching to meet the profession of education personnel. In carrying out these activities, prospective teachers will get direct guidance by advisors, guardian teachers, staffs and all staffs associated with educational activities. Success or failure depends on the efforts given by prospective teachers themselves. If a prospective teacher is able to conduct effective and intelligent constructive works, then the prospective teacher will be able to achieve the expected results.

Before a prospective teacher is brought to an exercise school, the prospective teacher will be equipped with basic teaching skills that should be understood and possessed by every prospective teacher. The basic skills will be provided through a micro teaching course, in which the prospective one will be equipped with basic skills of opening and closing lessons, questioning skills, strengthening skills, basic skills of explaining, basic skills of classroom management and basic skills of varying in teaching methods. In the courseof micro teaching, the prospective teachers are prepared to be the real teachers, namely the teacher who truly understands how to implement the teaching and learning process well so that the learning objectives can be achieved effectively and efficiently. Through the micro teaching course giving more orientation to teaching practice, it is the first step that must be faced by prospective teachers so that during the lecturing process, they can develop their potentials as teachers. This is similar to that expressed by Sardiman [6], that Micro teaching is one of the efforts undertaken in order to improve the skills of a teacher in developing his teacher profession. Micro teaching for every prospective teacher also serves as a preparation to face field practice; in microteaching activity, the prospective one is trained to show his activeness and ability as a teacher both to colleague friends and lecturers, so the microteaching is the beginning to determine the success of prospective teachers in the field (practice school).

\section{CONCLUSION}

Practice Field of Economic Education Students FKIP UMMY Solok year education of 2013 have been in good category, ranging from the skills of opening lesson to closing of learning activities. In addition, there has been an improvement by students after the basic knowledge of teaching skills in micro teaching courses, although there is still a weakness or lack in mastering the basic skills of teaching, especially on the basic skill of explaining.

Students should be better prepared in the implementation of teaching and learning process, especially in mastering materials so that students can minimize the weaknesses in mastering basic skills of explaining. In addition, students should read more references other than the package book used at the time of teaching so that there will be better mastery of materials at the time of teaching process.

\section{REFERENCES}

[1] O. Hamalik, Proses Belajar Mengajar. Jakarta: Bumi Aksara, 2009.

[2] A. Rohani, Pengelolaan Pengajaran: Sebuah Pengantar Menuju Guru Profesional. Jakarta: Rineka Cipta, 2010.

[3] Slameto, Belajar dan Faktor-faktor yang Mempengaruhinya. Jakarta: Rineka Cipta, 2010.

[4] S. Djam'an and S. Y. Sunaryo Kartadinata, "Profesi keguruan." Universitas Terbuka, Jakarta, 2007.

[5] B. U. Hamzah, Profesi kependidikan. Jakarta: Bumi Aksara, 2007.

[6] S. A.M., Interaksi dan motivasi belajar mengajar. Jakarta: Rajawali Pers, 2011.

[7] A. Sabri, Strategi Belajar Mengaja dan Micro Teaching. Jakarta: Ciputat Press, 2007

[8] D. N. Saputri, Siswandari, and Ngadiman, "Pengaruh Micro Teachingdan Bimbingan Guru Pamong terhadap Kemampuan Mengajar Mahasiswa PPL FKIP UNS Surakarta," J. Pendidik. Ekon., vol. 1, no. 1, 2013.

[9] S. Arikunto, Prosedur Penelitian: Suatu Pendekatan Praktik. Jakarta: Rineka Cipta, 2006.

[10] N. S. Sukmadinata, Metode penelitian pendidikan. Bandung: Remaja Rosdakarya, 2011

[11] A. A. Cahyati, "Pengaruh Mata Kuliah Micro Teaching Dan Praktik Pengalaman Lapangan (PPL) Terhadap Tingkat Kematangan Calon Guru Pada Mahasiswa Pendidikan Ekonomi Akuntansi Angkatan 2010 Universitas Muhammadiyah Surakarta," Universitas Muhammadiyah Surakarta, 2014. 